\title{
Does Europe Exist as an Entity for Military Cooperation? Evolving Russian Perspectives, 1991-2004
}

\section{Andrew Monaghan *}

A sea-change has taken place in Russian perspectives of Western European military integration since 1991. ${ }^{1}$ In the early 1990s, the Western European Union (WEU) and the European Union's Common Foreign and Security Policy (CFSP) were largely ignored in Russia. The Russia-WEU relationship was virtually non-existent, as was any discussion of the CFSP. According to Vladimir Baranovsky, "everything that related to the creation of Eurocorps or efforts to reanimate the WEU were viewed as not worthy of attention."2 One reason for this was that existing European military mechanisms were not considered effective for the regulation of conflicts and crises. ${ }^{3}$ Indeed, according to politician Vladimir Ruizhkov, the question of a military relationship between Russia and Europe "a few years ago ... would have looked absurd."4 Yet by 2003, European military integration — and Russian engagement with it — was considered to be among the most important priorities for the Russian Ministry of Foreign Affairs (MID). ${ }^{5}$ Two main processes had raised Europe's profile in military security discussions in Russia: the conflation of the WEU with the European Union (EU) and the intensification of the CFSP. These processes were seen to provide further arguments that the EU was becoming a serious international actor. ${ }^{6}$ Symptomatic of this shift in Russian perspectives, a military relationship between Russia and the EU has

* Andrew Monaghan is a Moscow-based Teaching Fellow at the Defense Academy of the United Kingdom, and a Doctoral candidate in the Department of War Studies at King's College, London.

1 The title of this essay is drawn from discussions in Russia in the United Europe Committee. N.K. Arbatova, ed., Rossiya i ES: bratya po oruzhiyu? (Moscow: Komitet 'Rossiya v Obidennoi Evrope,' 2003).

2 V.G. Baranovsky, "Common European Security and Defence Policy: Horizons of the Russian Perception," Connections: The Quarterly Journal 1:1 (January 2002): 23.

3 Yu.A. Borko, V.M. Kudrov, and B.M. Pichugin, Bezopasnost budushchei Evropui (Moscow: Nauka,1993), 98.

4 V. Ruizhkov, in Rossiya i ES, 1.

5 I.S. Ivanov, "The Foreign Policy Concept of the Russian Federation," in The New Russian Diplomacy (Washington, D.C.: The Nixon Center and Brookings Institution Press, 2002), 178; N. Revenko, in Rossiya i ES, 51.

6 V.G. Baranovsky, "Russian Views on NATO and the EU," in Ambivalent Neighbors: The EU, NATO and the Price of Membership, eds. A. Lieven and D. Trenin (Washington, D.C.: Carnegie Endowment for International Peace, 2003), 284; D. A. Danilov, "Obshchaya vneshnaya politika i politika bezopasnosti," in Evropeiski soyuz na poroge XXI veka. Vuibor strategii razvitiya, eds. Yu.A. Borko and O.V. Buturina (Moscow: URSS, 2001), 166. 
developed. Military-political links have been established, discussions over crisis response concepts held, and Russian participation in EU operations has begun. ${ }^{7}$

This article elaborates the evolution of this change, first looking at Russian attitudes towards the WEU, and then evolving Russian perspectives on CFSP/ESDP. Finally, the article looks at Russian views of progress made in the Russia-Western European military relationship, highlighting reasons why Moscow considers that the relationship has not progressed further. The article suggests that three main periods can be discerned. First, from 1991-1994, Russian views of European military integration were largely negative. Between 1994 and 2000, this attitude became both increasingly attentive and positive, reaching a peak between 1997 and 1999. However, from late 1999 onward, although official policy has remained positive, the mood in Moscow has swung towards disappointment with the WEU and ESDP.

In the early 1990s, Russian perspectives on the WEU were negative. Seen as a "relic of the Cold War," it was connected with friction and potential conflict with Russia. ${ }^{8}$ The leadership of the WEU was criticized in late 1993 for its Cold War mentality, and for adopting a didactic tone towards Russia, as reflected in the WEU General Secretary's lecture on the new European security architecture. ${ }^{9}$ The Russian elite was largely critical of the WEU's ability to carry out operations independent from the U.S. and its inability to act as a unified identity with regional security interests. Experts considered that a long list of problems were likely to undermine the WEU's ability to become an important security institution in Europe. These included member states' unwillingness to weaken their own sovereignty in the military sphere, internal contradictions within the WEU-EU-NATO system, legal constitutional obstacles, and the complex nature of consensus control over nuclear weaponry. The nuclear factor was considered a major stumbling block to European independence in this field, since it would be very difficult for Europeans to achieve consensus on the nuclear issue. Moreover, any consensus would produce a severely negative reaction from the U.S., and would therefore be counter-productive. Thus, Western Europe was "doomed to stay as an object, not an active subject" in international security. ${ }^{10}$

Nevertheless, a change began to take place in expert and political circles in roughly 1994. Researchers began to examine the importance of the WEU for Russia and also the Russia-WEU relationship. The increasing activity and strength of the WEU's practical functions, combined with the changing strategic landscape after the Cold War, slightly raised the organization's profile in Russia. Colonel Lelekhov considered that "'independence' of the [WEU] will apparently be reduced to the nominal 'Euro-

7 Russia-EU Joint Statement 29 May 2002, at www.eur.ru/eng/neweur/summits/sum5252.doc; Russia-EU Joint Statement 31 May 2003, at www.eur.ru/eng/neweur/user_eng.php?func= sum7.

8 V.N. Chernega, “Zapadno-evropeiski soyuz v teni NATO," Mezhdunarodnaya Zhizn' 8 (1998): 56.

9 G.B. Karasin, Diplomaticheski Vestnik 21:2 (1993): 71.

${ }^{10}$ N.A. Kosolapov and M.A. Strezhneva, Rossiya $i$ budushchee yevropeiskii ustroistvo (Moscow: Nauka, 1995), 38-50; Borko, et al. Bezopasnost. 
pean' reliance on NATO where the U.S. will continue to play a leading role. Nonetheless, the decision by the WEU to create its own armed forces has been made." Projects being developed by the WEU, he noted, might potentially include Russian participation in the future. ${ }^{11}$ Moreover, since the WEU was developing concepts for reaction to threats to European security contacts, it was considered "not without interest" by Russian officials. ${ }^{12}$

Indeed, many Russians viewed the WEU as having increasing significance as an actor in the European security architecture. The building of a "Greater Europe," argued Vladimir Chernega, required the deepening of interaction between all European structures, including strengthening the WEU. Then-Foreign Minister Kozyrev visited and addressed the WEU Assembly in December 1994, announcing that Russia considered cooperation with the WEU to be a means toward the end of strengthening European peace. $^{13}$

The WEU's links with other institutions also raised its profile within Russia. Considered in Russia to be a defense component of the EU, the WEU was in this respect seen to raise the prospect of collective Western European action in the security sphere, since it would be carrying out the EU's mandate of prosecuting peacekeeping operations. The activation of the Petersburg Tasks in 1994 made this particularly salient. Political factors, such as the strengthening of Russia's relationship with the EU-reflected in the signing of the Partnership and Cooperation Agreement in 1994-also raised the profile of the WEU in Moscow. With NATO enlargement looming, the WEU suddenly was endowed with the role of the "European arm of NATO." Auspiciously, a convergence emerged between the Russian concept of partnership in relations with the WEU and the WEU's own. This shared notion was reflected in a desire for gradual political progress towards the exchange of information to improve transparency and establish a climate of confidence. ${ }^{14}$

Russian interest in the WEU first manifested itself at senior official levels in mid1994, when President Yeltsin approved a document suggesting areas in which Russia would like to cooperate with the WEU. In announcing this shift toward a more positive perspective on the WEU, and the desire to establish a relationship with it, Moscow suggested an initiative to establish a combined group of Russian and WEU experts to

11 A.A. Lelekhov, “On Plans for Organising European Missile Defence," Voennaya Mysl' 1 (1994).

12 V. Churkin, interviewed in Sevodnya, 22 May 1995. Churkin was then Russian Ambassador to Belgium and Russian Representative to NATO Headquarters. In 1997-98, he took part in meetings with the WEU.

${ }^{13}$ Chernega, "Zapadno-evropeiski," 61. Chernega was Senior Advisor for foreign policy planning in MID.

${ }^{14}$ Interview with Dmitri Danilov of the Institute of Europe, 14 January 2004. A. Zagorski, "Russia and European Institutions," in Russia and Europe: The Emerging Security Agenda, ed. V. G. Baranovsky (Solna: OUP, 1997), 531; V.V. Zhurkin, Evropeiski Soyuz: Vneshnyaya politika, bezopasnoct', oborona, Report of the Institute of Europe 47 (Moscow: Institute of Europe, 1998), 30. 
draft a report considering the problems of European security. Moscow also suggested deepening consultations with the WEU on the European security architecture in order to facilitate practical cooperation with the WEU in peacekeeping operations, the resolution of the crisis in the Former Yugoslavia, and combined fleet peace support operations. The sale of Russian satellite imagery to the WEU and cooperation on coordinating tactical missile defense were suggested as well, as was the sale of military aircraft. ${ }^{15}$ The goal was to create a stable Russia-WEU partnership that fit into the overall pattern of Russian relations with NATO and the EU.

Russian efforts to intensify Russia-WEU dialogue and institutionalize cooperation began in May 1994. In October, parliamentary contacts (originally established in 1987 between the WEU and the Soviet Union) were resumed, providing the basis for what Andrei Zagorski called "intensive contacts." ${ }^{\text {"16 }}$ Beginning in 1995, Russia was regularly invited to send parliamentary observers to participate in WEU Assembly plenary sessions. Nonetheless, relations remained informal. The improving relationship-which shifted into a "somewhat higher gear" from 1996-98 - was reflected in a dramatic increase in meetings. Then-Foreign Minister Primakov again suggested formally institutionalizing relations in 1997, reflecting growing Russian interest in developing political and military cooperation with the WEU. ${ }^{17}$

Meetings between Russia's ambassador in Brussels, the General Secretary of the WEU, and the President of the WEU Council became regular by 1998, and the WEU's decision recommending that relations with Russia be upgraded to permanent institutional levels was well received in Russia. ${ }^{18}$ The establishment of a Russian delegation to the WEU Assembly in 1999 allowed Russia to observe European military projects and make its views on them known. ${ }^{19}$

The conflation of the WEU with the EU meant that the significance for Russia of cooperation with the WEU was broader than the actual practical results of the relationship, since it had implications for the overall Russia-EU relationship. In expert and official circles there was broad comprehension of the terms and process of this conflation: the WEU was understood to have been absorbed by the EU. ${ }^{20}$ The substantive merger (experts noted that, although the EU had taken over a number of the WEU's

${ }^{15}$ Churkin; K. Zueva, "Problemui zapadnoevropeiskovo soyuza i rossiya," MEIMO 4 (1997), 37.

${ }^{16}$ Zagorski, "Russia and European Institutions," 530-31. Zagorski is Deputy Director of the Konrad Adenauer Institute, Moscow.

${ }^{17}$ D. Danilov and S. de Spiegeleire, From Decoupling to Re-coupling: A New Security Relationship Between Russia and Europe? Chaillot Paper No. 31 (Paris: ISS, 1998), 17-19; S. Rogov, "Russia, NATO, and Western European Union," in Western European Union, 1954-1997: Defence, Security, Integration, ed. A. Deighton (Oxford: European Interdependence Research Unit, 1997), 90.

${ }^{18}$ Chernega, "Zapadno-evropeiski," 56; Zhurkin, Evropeiski Soyuz, 58.

${ }^{19}$ O.N. Barabanov, “Oboronnaya politika ES i Rossiya: vozmozhno li vzaimodeistviya?" Paper presented at the conference, "10 let vneshnei politiki Rossii," available at www.rami.ru.

20 Zhurkin, Evropeiski Soyuz, 48-9; Chernega, "Zapadno-evropeiski," 58-9. 
agencies, the two organizations officially still existed separately) was considered to have created a qualitatively new situation in Europe. ${ }^{21}$ Policy reflected this: Russia's Mid-term Strategy sought to include the WEU in the development of Russia's position on ESDP, as well as to deepen its political and military contacts with the WEU as an integral part of the EU. ${ }^{22}$

There were mixed views about the desirability of this conflation, to be sure. Some suggested that the possibility of the resurrection of the Cold War was becoming increasingly real. ${ }^{23}$ Others were more positive. According to Baranovsky, for example, Moscow has "never expressed any objections to the EU's coalescence with the WEU," and Dmitri Danilov believed that the addition of the Russia-WEU dialogue to the Russia-EU interaction "could be seen to be to everybody's advantage." 24

By mid-1999, the WEU had become the subject of localized but nevertheless rigorous Russian analysis. It was examined in considerable depth, with researchers conducting detailed assessments of its intrinsic value as a military player, including its evolving structures, tasks and capabilities, the WEU enlargement processes ("even more voluminous" than that of NATO, and conducted as if "on the sly," according to journalist Evgenii Grigoriev), and its relationship with the EU and NATO ${ }^{25}$ The WEU was considered in Russia to be undergoing "dynamic development" during the last years of the 1990s. This would, it was then believed by some, strengthen its political position and increase its potential in defense operations. ${ }^{26}$ It had become necessary for Russia to engage actively with it.

After 1999, the WEU was considered to have some value as a forum for the discussion of strategic issues. Senior Russian military officials addressed the WEU Assembly in 2001, and Vladimir Lukin addressed the Assembly in March and September 2003 on the conflict in the Middle East and the war against terrorism. ${ }^{27}$ Conferences were also jointly organized between the Russian parliamentary assemblies and the WEU Assembly to discuss current and future trends.

${ }^{21}$ S. Tkachenko, "EU enlargement and Russia's Security Concerns," in Russia and the European Security Institutions: Entering the Twenty First Century, ed. D. Trenin (Moscow: Carnegie Institute, 2000), 68.

${ }^{22}$ Russia's Mid-Term Strategy Towards the EU, available at www.eur.ru.

${ }^{23}$ I. Maksimichev, "Crisis of Confidence: NATO's Balkan Adventure Brought Europe to the Threshold of a New Cold War," in European Union, Russia and the Baltic Situation, eds. V. V. Zhurkin and N. A. Kovalsky (Moscow: Interdiktat, 2000), 76.

${ }^{24}$ V.G. Baranovsky, "Russian Foreign Policy Priorities and Euro-Atlantic Multilateral Institutions," The International Spectator 30:1 (1995): 41; Danilov and De Spiegeleire, From Decoupling to Re-coupling, 44.

${ }^{25}$ E. Grigoriev, "Voennaya ruka ES," Nezavisimaya Gazeta, 20 May 1999; D. Danilov and A. Moshes, Structurisatsiya prostranstva bezopasnosti na zapade i vostoke Evropui, Institute of Europe Paper No. 70 (Moscow: IoE, 2000).

${ }^{26}$ Danilov, "Obshchaya vneshnaya politika,"186.

${ }^{27}$ See www.assembly-weu.org/en/documents/colloques/cr/2003/athens_cr_web.html; www. assembly-weu.org/en/documents/colloques/cr/2003/cr_baveno.html. 
Since 1998, however, Russian attention has increasingly focused on the developing CFSP process, and the evolution of ESDP. CFSP/ESDP was considered to be a different organizational process for two main reasons. First, ESDP was initially believed to be more autonomous than the WEU, since the WEU's Atlantic connection was considered much stronger. Second, the demilitarization of European politics was very important for Russia. The WEU had just one function - a military alliance. The EU's military capability, on the other hand, was only one function of a much broader political and civilian organization. In this light, ESDP was seen as part of the broader demilitarization of Europe, playing an auxiliary role in the framework of a more complex security structure and thus contributing to the dismantling of remaining vestiges of the Cold War-era military confrontation. ${ }^{28}$

CFSP was welcomed by some in Russia, even in the early 1990s. Although Baranovsky considered the possibility of the EU sending military forces to Yugoslavia with a peacekeeping or disengagement mission definitely beyond its scope, he observed that "the fact that they were carried out by the 'twelve' is very impressive." 29 Nevertheless, it was with first the signature (1997), and then the entry into force (1999), of the Amsterdam Treaty that CFSP/ESDP was accorded more attention in Russia. The Treaty was seen as defining more clearly the intentions and foundations of CFSP, and was considered to stimulate both new political vigor and create a more operational foreign and security mechanism for the EU.

Great Britain's policy shift towards support for European defense was seen as one reason for this. Another was the Kosovo crisis in 1999 which, in highlighting Europe's inability to act independently in this dimension, stimulated European efforts to redress the imbalance. The EU's Collective Strategy towards Russia (CSR) of July, followed by the decision to create the Rapid Reaction Force in December 1999 was seen as settling a range of questions connected with the EU's crisis resolution and regulation capabilities, and was also seen as granting the ESDP a more operational character. ESDP was considered to be moving from the planning and project towards practical realization. $^{30}$

This period, particularly from 1999 on, has in Russia been considered to represent something of a "qualitative breakthrough," and in consequence increased attention was

${ }^{28}$ Danilov, interview, 14 January 2004.

${ }^{29}$ V.G. Baranovsky, "Political Changes in Europe," in The Security Watershed - Russians Debating Defence and Foreign Policy after the Cold War, ed. A.G. Arbatov (London: Gordon \& Breach Science Publishers, 1993), 256.

${ }^{30}$ Danilov, "Obshchaya vneshnaya politika," 189-90; E.E. Gorbatova, Obshchaya vneshnyaya politika i politika bezopasnosti evropeiskogo soyuza, Report of the Institute of Europe No. 115 (Moscow: IoE, 2002), 21-22; O. Barabanov, "Main Trends in EU Common Foreign and Security Policy Development and the WEU: An Unexpected Challenge for Russia?," in Russia and the European Security Institutions: Entering the Twenty First Century, ed. D. Trenin (Moscow: Carnegie Institute, 2000), 92-94; V.V. Zhurkin, I.F. Maksimichev, V.G. Mashluikin, and Yu.V. Shishkov, Evropa v mnogopolyarnom mire, Report of the Institute of Europe No. 66 (Moscow: IoE, 2000), 69-72. 
paid to ESDP - even to the extent that it became exaggerated in importance by some Russians, who accorded it more value than warranted. ${ }^{31}$ This attention should not be overplayed, however. Despite official statements that the EU's evolving military dimension should become a topic of special consideration, widespread analysis has not ensued. ESDP attracted very little coverage in either the Russian public press or in specialist analytical journals. The media organs of the Russian General Staff, Ministry of Defense, and MID have published few articles even alluding to it. This is particularly salient considering the significance of these departments in the formulation and implementation of Russian foreign and security policy.

Moreover, even this "qualitative breakthrough" period was considered one of "new horizons, old problems." 32 Practical and political problems were discerned, including the vagueness of institutionalization and the stages of integration in CFSP. The process was deemed very slow, uncertain, and plagued by backward steps and much internal competition. ${ }^{33}$ Thus the intensification of ESDP was considered by officials and politicians to only indicate the beginning of real movement towards the strengthening of the EU's military-political instruments. ${ }^{34}$

Nonetheless, the combination of ESDP with the CSR did highlight ESDP's significance for Russia, and raised potential problems for Moscow. CSR stated that the EU would export stability to its periphery, and also work with other major international actors. Yet Russia's position was ambiguous. Russia was a major international player, and therefore a potential partner in the regulation of problems and crises. But Russia was also a potential object of this "export of stability," particularly given the level of instability in western and south-western Russia. This duality had great significance for Russia, and meant that Russian policy had either to engage with the EU, or risk becoming an object of EU policy. ${ }^{35}$ This was underlined following the Helsinki Summit, when one analyst noted that EU decisions made regarding Russia were "extremely strict," and could represent the start of a significant shift in priorities and "a recoil" from Russia. ${ }^{36}$ This reflected concerns that ESDP may develop into a tool for exporting stability to its Russian neighbor, whether it was welcome or not.

Officially, nevertheless, the evolution of the Russia-ESDP relationship took place in a positive political atmosphere. The first joint statement - driven by Russian initiative - on strengthening dialogue on defense was made following the (sixth) EU-Russia summit in Paris in 2000. This was the first time that Russia had expressed a positive view of ESDP at the highest level, and represented its intentions to promote cooperation. Agreements made at this summit were judged to represent a "big step forward," according to analysts, and although the statement was a skeleton document, it did af-

${ }^{31}$ Baranovsky, "Russian Views on NATO and the EU," 284.

${ }^{32}$ Danilov and Moshes, Structurisatsiya prostranstva, 43.

${ }^{33}$ Barabanov, "Main Trends," 85-6.

${ }^{34}$ Ruizhkov and Revenko, both in Rossiya i ES, 52, 62.

${ }^{35}$ Gorbatova, Obshchaya vneshnyaya politika, 49-52.

${ }^{36}$ Barabanov, "Oboronnaya politika." 
ford Russia the ability to further develop channels for Russia-EU dialogue. ${ }^{37}$ Subsequent agreements were made at the May 2001 Russia-EU summit by each party to inform the other about their defense policy developments and implementation. ${ }^{38}$ Decisions to intensify this dialogue and cooperation, particularly on more operational aspects, and introduce monthly meetings between the Russian Ambassador and COPS to sum up crisis prevention and management consultations, were seen in Moscow to be the most important decision of the October 2001 Russia-EU Summit. President Putin was reported to hope to gradually transform this dialogue mechanism into a continual joint organ, ${ }^{39}$ and high-level military meetings began in 2001.

These developments gave rise to greater debate about it in Russia among experts and politicians, and the appearance of a broad range of EU enthusiasts and alarmists was noted by one analyst. ${ }^{40}$ The enthusiastic line argued that European defense integration did not pose a threat to Russia. The WEU was not considered a threat; without a significant military machine and bureaucracy, it possessed no structural ability to carry out large-scale military operations. And since ESDP was still relatively amorphous, neither was it considered a danger. The lack of any overt threat meant that the WEU/ESDP was viewed in a more benevolent light by some Russian officials. Moreover, no conflict of security interests between Russia and the EU was discerned; indeed, the "enthusiasts" suggest that they share similar security concerns. ${ }^{41}$

Real alarmism has not flourished. Yet few in Russia can today be considered genuine "enthusiasts" for the process of European military integration and ESDP for two main reasons. First, it was hoped that the WEU/ESDP would encourage the "Europeanization" of security in Europe and result in a more independent Europe in world affairs. For much of the 1990s, one of the main reasons for Russian interest in WEU/ESDP was their character as European institutions: they could provide the basis for a new, more inclusive, pan-European security architecture. This inclusive structure would strengthen stability on the continent, according to Deputy Chief of Staff Manilov. ${ }^{42}$ Such hopes, however, have faded.

European military integration processes were idealized by some in Russia, because it was imagined that they would enhance the role of Europe as a subject in international

${ }^{37}$ Ibid, 8.

38 "Russia-EU Summit Confirmed the Adherence of its Participants to the Development of Closer Cooperation in Europe," Pravda.ru, at http://english.pravda.ru/world/2001/05/17/ 5413.html.

${ }^{39}$ V. Sokolova, "ES i NATO tak i ne smogli otkazat'cya ot kliche," Strana.ru, at http://www.strana.ru/stories/01/10/01/1671/66819.html.

${ }^{40}$ Baranovsky, Russia's Attitudes, 107-8.

${ }^{41}$ Rogov, in Western European Union, 1954-1997, 88; Danilov, EU's Rapid Reaction Capabilities; S.L. Tkachenko, "EU's Crisis Management From the Russian Perspective," in EU Civilian Crisis Management, CSRC Document M22, eds. G.P. Herd and J. Huru (2001); A. Arbatov, in Evrobezopasnost': est li v nei mesto dlya Rossii?, ed. N.K. Arbatova (Moscow: Komitet 'Rossiya v Obidenennoi Evrope', 2002), 4.

${ }^{42}$ See www.assembly-weu.org/en/presse/cp/2001/15.html. 
affairs, enhancing multi-polarity in the world by countering U.S. hegemony. This could be also transformed into a strategic cooling-off period between the U.S. and the EU. In fact, in the mid 1990s, Russia's policy towards European military integration was an explicit function of its policy towards NATO and the U.S. military presence in Europe. The WEU was considered to be a tool for resolving disagreements between the EU and NATO, and its strengthening was seen to provide an opportunity to postpone NATO enlargement, or give it a more acceptable political cast. ${ }^{43}$ Similarly, ESDP was originally considered mainly from the angle of EU-NATO rivalry. As a result, Russian attitudes were more benevolent towards it as the incarnation of an alternative project to NATO. $^{44}$

Accordingly, the intervention in Kosovo produced a dual response in Russia, at once heightening awareness of the EU's desire to intensify CFSP/ESDP and yet also vividly demonstrating the EU's inability to act as an independent player in the security sphere. In sum, it had a negative effect on Russian perspectives of EU security capabilities. Moscow's reliance on Europe's political - and particularly its securityautonomy was substantially decreased, since NATO continued to wield significant influence in ESDP decision-making. This lack of autonomy generated disappointment in Russia. Analysts noted the growing impression in Russia that the EU was intentionally becoming a military and political subsidiary of NATO, and that the ERRF was unlikely to become anything but a NATO "mercenary reserve." 45 Thus, senior analysts argued, "Russia should not relax": Europe was insufficiently independent in the political sense from NATO and the U.S., and therefore still posed a potential threat to Russia. Many factors, such as NATO enlargement, its policy on Yugoslavia, and the perceived openly subversive policy of the U.S. in the Caucasus (and Europe's support for it), were cited as evidence of the possibility of EU resources being used against Russian interests. ${ }^{46}$ Senior military officers also criticized the close and continuing links between NATO and ESDP. Manilov stated that Russian military officials stood for cooperation with ESDP, but not with the one formulated so far. This was because they were against the EU's security forces becoming an "appendix to NATO's military machine." ${ }^{47}$ The perceived inability of the EU to play a significant independent role in security after September 11, 2001 has reinforced this image. ${ }^{48}$ So although it seems

${ }^{43}$ P. Felgenhauer, "Zapadnoevropeiski soyuz i Rossiya," Sevodnya, 07 June 1996; interview with Timofei Bordachev, Moscow, 26 November 03.

${ }^{44}$ V.G. Baranovsky, Russia's Attitudes Towards the European Union: Foreign and Security Policy Aspects (Helsinki: 2002), 104; Barabanov, "Main Trends," 97.

${ }^{45}$ A. Simonov, "Po perimetru evropui," at http://nvo.ng.ru/concepts/2001-08-10/ 4 perimetr.html; Maksimichev, in European Union, Russia and the Baltic Situation, eds. V.V. Zhurkin and N.A. Kovalsky (Moscow: Interdiktat, 2000), 75.

${ }^{46}$ N.P. Shmelev, in European Union, Russia and the Baltic Situation, 30.

${ }^{47}$ Cited in Baranovsky, Common European Security, 25.

${ }^{48}$ N.K. Arbatova, ed., NATO, Rossiya i evropeiski soyuz (Moscow: Komitet 'Rossiya v Obidenennoi Evrope', 2003), 7. 
that the idea of European defense integration was seen positively in Moscow, its implementation was received much less warmly.

Linked to this was a second set of problems, which focused on disappointment with the WEU/ESDP more specifically. Disappointment grew over the failure to realize cooperative projects. Russia expected a "considerably higher pace of rapprochement." Thus, the May 2001 Russia-EU summit, despite the agreements noted above, also provoked skepticism because of the evident failure to produce the expected tangible results. ${ }^{49}$ According to Andrei Kokoshin, this disappointment was further fuelled by the juxtaposition and comparison of the state of Russia-EU relations with the very positive relationship between Russia and the U.S. ${ }^{50}$

Noteworthy tangible results of practical cooperation are few. Although a contract for satellite imagery sales to the WEU was signed, Russian suggestions for cooperation in military technology, such as the sale of strategic airlift capabilities, remain unfulfilled. The impression in Russia was of Russian overtures being rejected by the WEU/ESDP, which hesitated in establishing such relations with Russia. For these projects to succeed, there had to be sufficient political will to implement them, an element considered notably absent. ${ }^{51}$

Crisis management was also seen to provide opportunities for practical cooperation. ${ }^{52}$ Dmitri Trenin, one of the most ardent Russian advocates of crisis management cooperation, considered that joint conflict prevention, management, and resolution were common interests. Moreover, he argued that transatlantic and Eurasian security could and should be linked by joint peace operations. In time, this could include combined Russian-European operations in such places as the Balkans, Moldova, and the Caucasus. $^{53}$

Since October 2000, such cooperation has been "routinely mentioned in practically all important meetings between the two sides." However, the vagueness of these references became routine, their future-oriented character underlining the "spectacular absence of real progress," Baranovsky averred. ${ }^{54}$ Five main reasons have undermined efforts to cooperate in crisis management. These reside at both strategic and operational levels.

First, a lack of strategic focus was clear to Moscow: the "EU suggests to Russia cooperation in peacekeeping, but does not say where in concrete terms; it suggests preparation for combined operations, but does not specify which exactly," Sergei Karaganov

${ }^{49}$ Baranovsky, Russia's Attitudes, 119.

${ }^{50}$ A. Kokoshin, "Voenno-strategicheskii vector dlya Rossii v 2003 godu," NVO, at http://nvo.ng.ru/wars/2003-01-17/1_triad.html.

${ }^{51}$ V. Dvorkin, "Perspektivui voennovo i voenno-tekhnicheskovo sotrudnichestva Rosii Evropui," in Bratya, ed. Arbatova, 15.

${ }^{52}$ Baranovsky, "Russian Views on NATO and the EU," 294.

${ }^{53}$ D. Trenin, A Russia-Within-Europe: Working toward a New Security Arrangement, IISS/ CEPS European Security Forum, Brussels (January 2002), at http://www.eursec.org/ trenin.htm.

${ }^{54}$ Baranovsky, Russia's Attitudes, 118-19. 
pointed out. ${ }^{55}$ This created impressions that the EU did not really want to cooperate with Russia. Such notions were reinforced by another strategic problem: it was believed by some in Moscow that Europe could and would not develop practical cooperation too far with Russia due to the EU's relationship with the U.S. Alexei Arbatov argued that the U.S. was concerned about ESDP, and if ESDP went into deep cooperation with Russia the results for Europe would be counterproductive. ${ }^{56}$ The possibility of genuinely profound cooperation was thus almost entirely ruled out by Moscow for strategic reasons.

Second, ongoing problems within WEU/ESDP meant that operational cooperation could not develop. Analysts noted the great difference between common policy and actual common defense, and Russian skepticism over the seriousness of the integration process continued. The WEU was seen as left without its own operational forces, and thus dependent on the goodwill of member states for human and material resources. Expensive technical upgrading was necessary and, lacking even the means to plan and command forces, it remained heavily dependent on NATO. Neither was any real unified European political will seen to exist; the unwillingness of member states to relinquish sovereignty in security matters was considered a major problem hindering any effective action by the WEU. ${ }^{57}$ Moscow also remained unconvinced that ESDP would actually come to fruition. Indeed, it was considered an exotic possibility rather than an impending reality. As a military tool, ESDP also lacked autonomous military resources and command structures, and was in fact considered incapable of raising sufficient armed forces without weakening the territories and sovereign interests of the member states. Thus Defense Minister Ivanov noted in 2001 that the abilities of the EU "to act effectively in crisis management" on the European continent were "not clear." sian military elites remained uninterested in ESDP as a serious issue requiring adequate assessments and analysis. The ERRF was simply not considered a real military instrument, since it would not be sent to fight in any major regional conflict. Instead, it was seen as a political instrument, aimed at completely different challenges. ${ }^{59}$ Thus Vladimir Lukin questioned whether Europe really was a partner for Russia in military cooperation. "What on earth are the characteristics of Europe in such a role? Where is this partner?" he enquired. ${ }^{60}$

Third, there is debate in Russia about the capabilities of the Russian armed forces themselves and their ability to cooperate with Western European forces. Although some believe that Russia could gather together the military capabilities to contribute to

${ }^{55}$ S. Karaganov, "Novuie vuizovi evropeiskoi bezopasnosti," in Evrobezopasnost', 22.

${ }^{56}$ Arbatov, in Evrobezopasnost', 17.

${ }^{57}$ Rogov, in Western European Union, 1954-1997, 85-88; Zueva, "Problemui zapadnoevropeiskovo," 32, 34, 40; Chernega, "Zapadno-evropeiski," 56-57, 60.

${ }^{58}$ Cited in Tkachenko, "EU's Crisis Management," 56.

${ }^{59}$ Karaganov, in Evrobezopasnost', 5, 21-22; V. Ruizhkov, "Introduction," in NATO, Rossiya i evropeiski soyuz, 7.

${ }^{60}$ V. Lukin, Rossiya i ES, 21-2. 
operations with Western European forces, ${ }^{61}$ many analysts and politicians argue that Russia does not possess appropriate military capabilities for such projects. The Russian armed forces were not considered to be in a fit state for cooperation with Western European forces on such operations. As Arbatov pithily declared, "if no one is afraid of the Russian army as an opponent, then everyone is afraid of it as an ally because of the way that the Russian army fights, as shown in Chechnya." ${ }^{2}$ There was widespread consensus, according to General Vladimir Dvorkin, Director of the Centre on the Problems of Strategic Forces, that Russia needed to conduct a radical reform of the structure of its armed forces before worthwhile cooperation with the ERRF could take place. This was particularly necessary in terms of military preparation and technological equipment. Moreover, doctrinal changes in the Russian armed forces were necessary, to heighten transparency and civilian control. ${ }^{63}$ Trenin argued that Russian forces would need to change tactics, forgoing the scorched-earth model and adopting counterterrorist tactics that would spare the population and minimize collateral damage. Indeed, close cooperation would require a "major overhaul of the Russian military system: in its present form and quality, only very limited and often mutually frustrating cooperation was feasible," he believed. ${ }^{64}$

Furthermore, issues of Russian domestic military and political opinion undermined chances of achieving practical cooperation. There was reluctance and skepticism on the part of the Russian military to engage in cooperation, since it raised questions of transparency. In practical specifics such as joint training there was reluctance: cooperation would expose problems within the Russian military system and expose the Russian military to criticism. Moreover, such reforms are not considered desirable by the Russian armed forces. Cooperation would stimulate the reform of the Russian Army. But in this new army, there would be no place for the old leadership, and so the army leadership remains resistant. ${ }^{65}$ Politically, nationalist and other hard-line elements within Russia were ambivalent about any outside participation in peacekeeping operations within the former Soviet Union, particularly if they originated with NATO or WEU/ESDP. ${ }^{66}$ So, as Andrei Zagorski phrased it "this depends on the evolution and maturing of the ESDP ... it also remains an open question the extent to which Russia will be able to share responsibilities with the EU., ${ }^{97}$

${ }^{61}$ Interviews in Moscow, November 2003, January 2004.

${ }^{62}$ Arbatov, in Evrobezopasnost',16; Bordachev, interview 2003.

${ }^{63}$ Dvorkin, in Rossiya i ES.

${ }^{64}$ D. Trenin, "From Pragmatism to Strategic Choice: Is Russia's Security Policy Finally Becoming Realistic?" in Russia After the Fall, ed. A. Kuchins (Washington, D.C.: Carnegie Endowment for International Peace, 2002), 198-99; Trenin, Russia-Within-Europe.

${ }^{65}$ Interviews: V. Baranovsky, November 2003; A. Goltz and S. Tkachenko, April 2004.

${ }^{66}$ A. Arbatov, "Russian Foreign Policy Thinking in Transition," in Russia and Europe, 153-54; Interviews, Moscow, April 2004.

${ }^{67}$ A. Zagorski, "Policies towards Russia, Ukraine, Moldova and Belarus," in European Union Foreign and Security Policy. Towards a Neighbourhood Strategy, ed. R. Dannreuther (London: Routledge, 2004), 85. 
A fourth problem was also clear: even if one or both sides were prepared, instruments did not exist for common actions in crisis management. Much preparatory work was still required to create effective consultation, decision-making, contingency planning, and inter-operability mechanisms, Danilov argued. ${ }^{68}$ Moreover, some asserted that Russian and Western politicians, military, and experts have to first overcome their disagreements, recognize respective peace support actions, perceive conflict situations from the other's viewpoint, and then develop viable solutions. Tense debates about how to conduct such international operations are ongoing. ${ }^{69}$

Russian observers consider that the political side of this relationship was the more important element of any potential interaction. The reason for strengthening RussiaEU interaction in this sphere was to ensure Russian participation in the European defense dialogue, and it was widely felt that this agreed with the overall framework of the Russia-EU strategic partnership. ${ }^{70}$ In this respect, therefore, some progress was made, and, as noted above, a framework for dialogue was established.

Even so, a fifth problem is that a profound unwillingness to involve Russia politically was noted in Moscow. European defense structures moved "much less willingly" towards dialogue with Russia than NATO, averred Barabanov. ${ }^{71}$ Russia-WEU political connections remained unsubstantiated, and relations continued on an ad hoc basis. The WEU was seen as holding back from institutionalizing the relationship, and was the only European organization without a permanent framework for dialogue and cooperation with Russia. Trenin argued that there was still a need for a single forum for Russia-European security relations. ${ }^{72}$ Moreover, news reports of Russia-EU summit declarations suggested that existing formats were being used neither efficiently nor fully for conducting dialogue. ${ }^{73}$ There were thus ongoing concerns in Moscow that this reluctance hid a desire to exclude Russia from European defense dialogues and enlarge Western European institutions at the expense of pan-European ones, undermining overall European security and stability ${ }^{74}$ Following Helsinki, this became more pertinent for Russia since a "hypothetically unfriendly EU emerged like hell from a snuff box," conducting itself in a more unfriendly fashion concerning Russian military action in Chechnya. ${ }^{75}$ Barabanov-acknowledging his provocative statement-argued that Russian perspectives on ESDP did recover with the improvement in overall Russia-EU relations in $2000-2001 .^{76}$ Nonetheless, the link is obvious: Russian perspectives on

${ }^{68}$ Danilov, EU's Rapid Reaction Capabilities, 5-6.

${ }^{69}$ A. Nikitin, ed., Peace Support Operations, Parliaments and Legislation (Moscow: Centre for Political and International Studies, 2004), 8, 13.

${ }^{70}$ Danilov, in Rossiya i ES, 48; Barabanov, "Oboronnaya politika."

${ }^{71}$ Chernega, "Zapadno-evropeiski," 58, 61; Barabanov, "Oboronnaya politika"; Baranovsky, "Russian Views on NATO and the EU," 293.

72 Trenin, Russia-Within-Europe.

${ }^{73}$ See http://english.pravda.ru/world/2001/05/17/5413.html.

${ }^{74}$ Zagorski, in Russia and Europe, 530.

75 Barabanov, "Main Trends," 98.

${ }^{76}$ Barabanov, interview 28 November 03. 
ESDP are an object of the holistic Russia-EU relationship. When the overall situation is under pressure, Russia sees ESDP as a potential risk, since it will be a tool of EU policy. The stronger ESDP becomes, the more salient this point will become. It is worth noting Defense Minister Ivanov's point that "only in a situation where Russia's voice is taken into account in shaping the EU's crisis management policy will Russia's position be more favorable towards the EU and their contacts constructive." 77

Thus questions have been raised about whether a militarily strong EU could become, if not a threat, then at least a risk to Russia's western borders. The lack of a clear-cut security agenda, which created problems for practical cooperation with Russia, also fosters uncertainties about how and where these increasing capabilities would be used, particularly whether they would always act in accordance with the UN. Concerns remain over where the EU intends to use its crisis management capabilities, and particularly that ESDP may be deployed in the territories of the former Soviet Union without Russian cooperation or approval, or even against Russia. ${ }^{78}$ The feel of a duality in Russia's role as envisaged in EU policy - as either a major partner or an object of EU policy-continues; however, the feeling in Moscow of Russia being an object rather than a partner is growing. ${ }^{79}$

In conclusion, it can be seen that Russian views of the WEU/ESDP are somewhat paradoxical. Practical cooperation was sought, and disappointment was evident when it did not occur. Yet it was understood that it could not have occurred. Also WEU/ESDP were idealized as the foundation of a new pan-European security architecture, providing an alternative to NATO. Yet it was clear that the resources were not there for this to happen. Finally, one of the main reasons why Russia's views were not more hostile-ESDP's "amorphous," non-threatening nature - meant that it remained rather in the blind spot of Russian foreign policy. This non-threatening, indeterminate stance even became a negative point for those who distrust the vagueness of the EU's aims. Five other key points concerning Russian perspectives on the Russia-EU military security relationship can be drawn.

First, and most importantly, a significant evolution of Russian perspectives on the WEU/ESDP took place during this period. At the beginning of the 1990s, the Russian elite barely recognized the existence of these organizations, let alone accorded them any value as relevant international security actors. Nonetheless, reflecting the increasing importance attached to European military integration processes, Moscow made more effort to interact with the WEU/ESDP, particularly since Moscow believed it could offer something that the WEU/ESDP lacked.

Second, however, this relationship simply could not develop very far in practical terms. Neither Russian nor Western European force structures were considered ready for cooperation in crisis management operations, nor did real doctrinal consensus or

\footnotetext{
${ }^{77}$ Cited in Tkachenko, "EU's Crisis Management," 56.

${ }^{78}$ Baranovsky, interview 27 November 03; interviews in Moscow, April 2004.

${ }^{79}$ Interviews, Moscow, April 2004.
} 
mechanisms to facilitate such cooperation exist. The relationship that developed has remained essentially symbolic.

Third, it was the political rather than the practical side of this dimension that was most important to Moscow. The establishment of permanent dialogue and official channels with the WEU and ESDP was the predominant Russian aim. This was intended to ensure ongoing flexibility in the relationship: if the WEU/ESDP became a major factor in international affairs, then such a dialogue would enable Russia to have its voice heard. It would also perhaps be able to influence the EU through such channels. Moreover, this dialogue would help to build transparency and establish a climate of confidence, which would also help bolster the overall relationship between Russia and the EU. Development of the political side would create a springboard for more concrete practical forms of cooperation at a later stage. A further important political interest in the WEU/ESDP for Russia during this period was its capability as a political pivot between NATO and the EU.

Fourth, and consequentially, although there was disappointment in Russia at the lack of progress made in practical terms, the real disappointments came from political failures, particularly the failure to create a formal, permanent relationship with the WEU, and to further develop the political relationship with ESDP. Despite the establishment of the COPS links and developing dialogue on security policy relations between Russia and the EU, which can be seen to represent a largely positive position for Russia, problems remained.

Fifth, and finally, the lack of a clear strategy for ESDP affected the relationship with Russia practically and theoretically. Russia has been left on the horns of uncertainty about the use of the EU's rapid reaction force, and has become increasingly frustrated with what is seen as EU dithering over the discussion of specific details of practical cooperation. This has two implications. First, due to the twin problems of the lack of developed, concrete political connections and the lack of independent military capabilities, the WEU has dropped off Russia's foreign and security policy radar altogether. In Russia there is now neither the political will to maintain relations, nor, indeed, sufficient expertise at the working level between Russia and the WEU to facilitate a relationship. There is no MID engagement in cooperation with the WEU. It is considered "headless," and no worthwhile analytical or political attention is expended on it. Russian experts consider these relations to be finished, and that the WEU effectively no longer exists. ${ }^{80}$ Perhaps of more concern for the future, there are some signs that ESDP may go the way of the WEU in Russian eyes. This is particularly the case since positive perspectives were largely founded on two points: global multi-polarity, and stability in Europe through a new, inclusive pan-European security structure. Neither of these points has really developed as hoped by Moscow. Moreover, progress towards the actual practical implementation of ESDP has been slow, and doubts are growing in Moscow over whether it will really be implemented.

${ }^{80}$ Interviews with Danilov and Maksimichev, Moscow, 14 January 2004, 15 January 2004. 
The second implication is that negative tendencies may thrive. Russian perspectives on European military integration remain vulnerable to vagaries in the overall RussiaEU relationship. Some very senior executive politicians have indeed made positive statements about ESDP, and a (diminishing) handful of analysts can still be considered "enthusiasts" for it. However, underlying the superficially institutionalized structure of Russia-ESDP relations, there is little driving support for it - and cooperation with itin Russia. Even some of those who have studied and supported European military integration in depth during the 1990s and can be considered "enthusiasts" seem to have become either disinterested or are turning away from it. Without this practical or theoretical support, the potential for Russian official perspectives on ESDP to turn negative certainly exists. If the overall tendencies behind the Russia-EU relationship become negative, Russian concerns that ESDP will be used against Russian interests may intensify. To again quote Defense Minister Ivanov: "we think that Russia's official position will quite soon become more negative towards the creation by the EU of its own military forces." ${ }^{\prime 11}$ This has not yet happened. However, Russian analysts have recently noted stricter and more demanding EU tones towards Russia, indeed, policies that "almost proclaim a new strategy of pseudo-deterrence." ${ }^{\prime 82}$ How this will resonate and impact on Russian perspectives on ESDP should be watched carefully.

${ }^{81}$ Cited in Tkachenko, "EU's Crisis Management," 56.

${ }^{82}$ See, for example, S. Karaganov, "The Perils of Pressuring Russia: Brussels vs. Moscow," International Herald Tribune, 25 February 2004. 


\section{Bibliography}

Baranovsky, V.G.. "Common European Security and Defence Policy: Horizons of the Russian Perception." Connections: The Quarterly Journal 1, no. 1 (2002): 22-28.

Baranovsky, V.G.. "Russian Foreign Policy Priorities and Euro-Atlantic Multilateral Institutions." The International Spectator 30, no. 1 (1995).

Borko, Yu.A., V.M. Kudrov, and B.M. Pichugin. Bezopasnost budushchei Evropui. Moscow: Nauka,1993, 1993.

Churkin, A. V., and K. Zueva. "Problemui zapadnoevropeiskovo soyuza i rossiya." MEIMO 4 (1997).

Ivanov, I.S.. "The Foreign Policy Concept of the Russian Federation." In The New Russian Diplomacy. Washington, D.C.: The Nixon Center and Brookings Institution Press, 2002.

Lelekhov, A.A.. "On Plans for Organising European Missile Defence." Voennaya Mysl 1 (1994).

Maksimichev, I.. "Crisis of Confidence: NATO's Balkan Adventure Brought Europe to the Threshold of a New Cold War." In European Union, Russia and the Baltic Situation. Moscow: Interdiktat, 2000.

Tkachenko, S.. "EU enlargement and Russia's Security Concerns." In Russia and the European Security Institutions: Entering the Twenty First Century. Moscow: Carnegie Institute, 2000. 